DOI https://doi.org/10.30525/978-9934-26-113-8-2

\title{
CECHY STANU FUNKCJONALNEGO WĄTROBY U PACJENTÓW Z NADCIŚNIENIEM W POLĄCZENIU Z OTYLOŚCIĄ I NAFLD
}

\author{
Boczar O. M.
}

Kandydat nauk medycznych, profesor nadzwyczajny Terapii №1, Diagnostyki Medycznej oraz Hematologii i Transfuzjologii Wydziału Kształcenia Podyplomowego Danylo Halytskyi Lwowski Narodowy Uniwersytet Medyczny

\section{Boczar V. T.}

Kandydat nauk medycznych, profesor nadzwyczajny Katedry Chirurgii i Transplantologii Wydziatu Kształcenia Podyplomowego Danylo Halytskyi Lwowski Narodowy Uniwersytet Medyczny Lwów, Ukraina

Wprowadzenie. Niealkoholowa stłuszczeniowa choroba wątroby jest najczęstszą patologią spośród wszystkich przewlekłych chorób wątroby. Ona często prowadzi do pogorszenia jakości życia pacjenta, niepełnosprawności i śmierci z powodu progresji stłuszczenia, niealkoholowego stłuszczeniowego zapalenia wątroby (NASH), zwłóknienia, marskości, niewydolności wątroby i raka wątrobowokomórkowego [1,2].

Częstość występowania NAFLD w różnych krajach waha się od 14-40\% [3]. Według literatury $w$ Stanach Zjednoczonych NAFLD jest jedną $z$ najczęstszych przewlekłych chorób wątroby, a wśród dorosłej populacji wynosi około $34 \%$ i rośnie z roku na rok [4].

Ostatnie badanie przeprowadzone przez The CARDIA Cohort Study (2018) pokazuje, że wzrost BMI w wieku 25 lat jest ściśle związany $\mathrm{z}$ występowaniem NAFLD $\mathrm{w}$ wieku średnim. Badanie udowodniło po raz kolejny, jak ważne jest zapobieganie tej chorobie poprzez utrzymywanie prawidłowej masy ciała [5].

W 14-20\% przypadków NAFLD łączy się z patologią układu sercowonaczyniowego, w szczególności z nadciśnieniem i chorobą wieńcową [6].

Meta. Oceń cechy stanu czynnościowego wątroby zgodnie $\mathrm{z}$ testem oddechowym 13C-metacetyny

Materiały i metody. Wszystkich 50 pacjentów z nadciśnieniem tętniczym $\mathrm{w}$ połączeniu $\mathrm{z}$ otyłością i NAFLD oznaczono za pomocą testów 
antropometrycznych, ogólnych klinicznych, laboratoryjnych (widmo lipidów we krwi), instrumentalnych (elektrokardiografia, echokardiografia, ultrasonografia) i immunoabsorpcji enzymatycznej (adiponektyna).

Ponadto, w celu określenia stanu funkcjonalnego mikrosomalnych układów enzymatycznych hepatocytów, wszyscy pacjenci przeszli test oddechowy z metacetyną znakowanym $\mathrm{C}^{13}\left({ }^{13} \mathrm{C}\right.$-methacetin breath test $-{ }^{13} \mathrm{C}$ $\mathrm{MBT}$ ). Badanie to pozwala na nieinwazyjną ocenę odsetka funkcjonujących hepatocytów, klasyfikację niewydolności wątroby na marskość i bez marskości oraz określenie jej stopnia według kryteriów Childa-Pugha. Czułość i swoistość ${ }^{13}$ C-MBT wynosi ponad 90\% [7].

Wyniki ${ }^{13} \mathrm{C}-\mathrm{MBT}$ pozwoliły ocenić antytoksyczną funkcję wątroby, określając jej zdolność metaboliczną i tempo metabolizmu hepatocytów po 40 i 120 minutach (dawka skumulowana - CUM40 i CUM120). Metoda ta umożliwia określenie proporcji funkcjonujących hepatocytów, a także różnicowanie stłuszczenia, stłuszczenia wątroby i zwłóknienia.

Wyniki opracowano statystycznie testem Studenta, analizą korelacji Pearsona przy użyciu programu komputerowego «Microsoft Excel».

\section{Wyniki badań i ich dyskusja.}

Po badaniu klinicznym i USG wyselekcjonowano 50 pacjentów w celu potwierdzenia rozpoznania NASH. Dokonano tego przy użyciu wysoce informacyjnego i bardzo czułego ${ }^{13} \mathrm{C}-\mathrm{MBT}$. Ten test pozwala określić procent funkcjonujących hepatocytów u pacjentów z objawami stłuszczenia wątroby. Grupa kontrolna składała się z 10 osób zdrowych.

Według ${ }^{13} \mathrm{C}$-MBT tempo metabolizmu stwierdzono w zakresie od 4,3 $\left(\%{ }^{13} \mathrm{C} / \mathrm{h}\right)$ do $18,5\left(\%{ }^{13} \mathrm{C} / \mathrm{h}\right)$, co średnio $(13,66 \pm 0,39)\left(\%{ }^{13} \mathrm{C} / \mathrm{h}\right)$, było to znacznie niższe o $46,7 \% \mathrm{w}$ porównaniu $\mathrm{z}$ grupą kontrolną $(\mathrm{p}<0,01)$. CUM40 było $(7,28 \pm 0,26)\left(\%{ }^{13} \mathrm{C}\right)$, CUM120 - $(12,69 \pm 0,57)\left(\%{ }^{13} \mathrm{C}\right)$.

Wyniki ${ }^{13} \mathrm{C}-\mathrm{MBT}$ wskazują na obecność stłuszczenia wątroby, którego czynnikiem prowokującym jest prawdopodobnie otyłość, której towarzyszą zmiany jej stanu funkcjonalnego. ${ }^{13} \mathrm{C}$-MBT umożliwiło wiarygodne ustalenie spadku funkcji hepatocytów i potwierdzenie diagnozy NASH.

Według naszych wyników wartości ${ }^{13} \mathrm{C}-\mathrm{MBT}$ były znacznie niższe $\mathrm{w}$ porównaniu $\mathrm{z}$ wartościami $\mathrm{w}$ grupie kontrolnej $(\mathrm{p}<0,01)$. CUM40 został zredukowany o $40 \%(\mathrm{p}<0,01)$.

Według ${ }^{13}$ C-MBT CUM120 został zredukowany o 46,8\% ( $\left.<<0,01\right)$.

Wśród pacjentów, u których wykonano test oddechowy, istotne objawy stłuszczeniowego zapalenia wątroby stwierdzono u $21(42,0 \%)$ pacjentów. Pozostałe 29 badanych $(58,0 \%)$ wykazywało oznaki stłuszczenia do stłuszczeniowego zapalenia wątroby. Za kryteria wiarygodnych objawów 
stłuszczeniowego zapalenia wątroby uznano jednocześnie wykryte zmiany we wszystkich 3 wskaźnikach, a wątpliwe objawy stłuszczeniowego zapalenia wątroby uznano za wykryte 2 zmiany (tempo metabolizmu i/lub CUM40 i/lub CUM120).

Według obliczeń matematycznych w stłuszczeniowym zapaleniu wątroby tempo metabolizmu wynosiło 0,48, CUM40 - 0,57 i CUM120 - 0,43, co odpowiadało umiarkowanemu zmniejszeniu funkcji detoksykacji wątroby i było istotnie mniejsze w porównaniu $\mathrm{z}$ grupą kontrolną $(\mathrm{p}<0,05)$.

$\mathrm{Na}$ podstawie danych matematycznych obliczeń $\mathrm{u}$ pacjentów $\mathrm{z}$ nadciśnieniem tętniczym $\mathrm{w}$ połączeniu $\mathrm{z}$ otyłością i NASH rozkład był $\mathrm{w}$ zależności od aktywności procesu zapalnego: u grupi $1-\mathrm{z}$ umiarkowanym spadkiem funkcji detoksykacji wątroby $(0,50-0,80)-27(54,0 \%)$ i u grupi 2 - z wyraźnym spadkiem funkcji detoksykacji wątroby $(0,25-0,50)-$ $23(46,0 \%)$ pacjentów. Nasze wyniki są zgodne z najnowszymi danymi innych autorów [8].

Oprócz ogólnej analizy wyników ${ }^{13} \mathrm{C}-\mathrm{MBT}$ przeprowadzono ocenę płci zmian wskaźników tego badania. U kobiet tempo metabolizmu wahało się od $8,8\left(\%{ }^{13} \mathrm{C} / \mathrm{h}\right)$ do $18,5\left(\%{ }^{13} \mathrm{C} / \mathrm{h}\right)$, średnio $13,79 \pm 0,52\left(\%{ }^{13} \mathrm{C} / \mathrm{h}\right)$ i było o $46,1 \%$ mniejsze niż w grupie kontrolnej. Podobne dane uzyskano dla CUM40 $(39,2 \%)$ i CUM120 (46,0\%) (p <0,01). U mężczyzn średnie tempo metabolizmu wątrobowego zmniejszyło się o $47,5 \%$ oraz zmniejszyło się CUM40 (40,8\%) i CUM120 (48,1\%), (p <0,01). Tak więc wskaźniki ${ }^{13} \mathrm{C}-\mathrm{MBT}$ wśród kobiet i mężczyzn nie różniły się znacząco od siebie.

Oceniając wyniki ${ }^{13} \mathrm{C}$-MBT u mężczyzn i kobiet, należy zauważyć, że tempo metabolizmu wątroby, CUM40 i CUM120, mieściło się w umiarkowanym obniżeniu jej funkcji detoksykacji.

\section{Wnioski}

Tak więc wyniki ${ }^{13} \mathrm{C}$-MBT wykazały umiarkowany spadek funkcji detoksykacji wątroby ze spadkiem tempa metabolizmu, CUM40 i CUM120 u pacjentów z nadciśnieniem tętniczym na tle otyłości i NAFLD w stadium stłuszczeniowego zapalenia wątroby, co zaobserwowano zarówno u mężczyzn, jak i kobiety.

Na podstawie wskaźników ${ }^{13} \mathrm{C}-\mathrm{MBT}$ spadok tempa metabolizmu CUM40 i CUM120 lub dwóch $\mathrm{z}$ nich lub jednego $\mathrm{z}$ nich można nieinwazyjno zdiagnozowaćaktywność procesu zapalnego w stłuszczeniowym zapaleniu wątroby i przewidzieć jego przebieg według szacunków zmniejszenija funkcji mitochondrialnej hepatocytów, co jest szczególnie ważne przy bezobjawowym przebiegu NAFLD. 


\section{Piśmiennictwo:}

1. Mundi M.S., Velapati S., Patel J. el al. Nutrition in Clinical Practice. 2020. №35(1). C.72-84. doi: 10.1002/ncp.10449.

2. Younossi Z., Anstee Q.M., Marietti M. et al. Global burden of NAFLD and NASH: trends, predictions, risk factors and prevention. Nature Reviews Gastroenterology \& Hepatology. 2018. № 15(1). C. 11-20. doi: 10.1038/nrgastro.2017.109.

3. Perumpail B.J., Khan M.A., Yoo E.R. et al. Clinical epidemiology and disease burden of nonalcoholic fatty liver disease. World Journal of Gastroenterology. 2017. № 21;23(47). C. 8263-8276. doi: 10.3748/ wjg.v23.i47.8263.

4. Estes C., Anstee Q.M., Arias-Loste M.T. et al. Modeling NAFLD disease burden in China, France, Germany, Italy, Japan, Spain, United Kingdom, and United States for the period 2016-2030. Journal of Hepatology. 2018. №69(4). C. 896-904. doi: 10.1016/j.jhep.2018.05.036.

5. VanWagner L.B., Khan S.S., Ning H. Body mass index trajectories in young adulthood predict non-alcoholic fatty liver disease in middle age: The CARDIA cohort study. Liver International. 2018 № 38(4). C. 706-714. doi: 10.1111/liv.13603. Epub 2017 Oct 13.

6. Targher G., Byrne C.D., Tilg H. NAFLD and increased risk of cardiovascular disease: clinical associations, pathophysiological mecha nisms and pharmacological implications Gut. 2020. № 69(9). C. 1691-1705. doi: 10.1136/gutjnl-2020-320622.

7. Gorowska-Kowolik K., Chobot A., Kwiecien J. ${ }^{13} \mathrm{C}$ Methacetin Breath Test for Assessment of Microsomal Liver Function: Methodology and Clinical Application Gastroenterology Research and Practice. 2017. № 2017. C.7397840. doi: 10.1155/2017/7397840.

8. Molina-Molina E., Shanmugam H., Di Ciaula A. et al. (13 C)Methacetin breath test provides evidence of subclinical liver dysfunction linked to fat storage but not lifestyle. JHEP Reports. 2020. №3(1). C. 100203. doi: 10.1016/j.jhepr.2020.100203. 